American Journal of Agricultural and Biological Sciences 4 (1): 18-23, 2009

ISSN 1557-4989

(C) 2009 Science Publications

\title{
Reduction of Ammonia Loss by Mixing Urea with Liquid Humic and Fulvic Acids Isolated from Tropical Peat Soil
}

\author{
${ }^{1}$ Susilawati Kasim, ${ }^{1}$ Osumanu Haruna Ahmed, ${ }^{1}$ Nik Muhamad Ab. Majid, \\ ${ }^{2}$ Mohd Khanif Yusop and ${ }^{3}$ Mohamadu Boyie Jalloh \\ ${ }^{1}$ Department of Crop Science, Faculty of Agriculture and Food Science, \\ University Putra Malaysia Bintulu Campus, Sarawak, 97008 Bintulu, Sarawak, Malaysia \\ ${ }^{2}$ Department of Land Management, Faculty of Agriculture, \\ University Putra Malaysia, 43400 Serdang, Selangor, Malaysia \\ ${ }^{3}$ School of Sustainable Agriculture, University Malaysia Sabah, \\ Locked Bag 2073, 88999 Kota Kinabalu, Sabah, Malaysia
}

\begin{abstract}
Problem statement: Fertilizer $\mathrm{N}$ use efficiency is reduced by ammonia volatilization. Under low soil CEC and high $\mathrm{pH}, \mathrm{N}$ from soil solution is released to the atmosphere. Ammonia loss due to low worldwide $\mathrm{N}$ use efficiency (33\%) has been implicated in global warming. Thus, the objectives of this laboratory study were to evaluate the effectiveness of liquid humic and fulvic acids, isolated from tropical peat soils in reducing $\mathrm{N}$ loss from urea fertilizer as well as to investigate the ability of these acids to retain $\mathrm{NH}_{4}{ }^{+}$and $\mathrm{NO}_{3}{ }^{-}$or reduce soil $\mathrm{pH}$. Approach: Formulated liquid $\mathrm{N}$ fertilizers consisting of urea and different types of humic molecules (HA or FA or mixture of both), solid and liquid urea were surface applied to $250 \mathrm{~g}$ of soil. A closed dynamic air flow system was used to trap $\mathrm{NH}_{3}$ loss in boric acid after which samples were titrated with $0.01 \mathrm{M} \mathrm{HCl}$ to estimate $\mathrm{NH}_{3}$ loss. After 30 days of incubation, the soil was air dried and analysed for $\mathrm{pH}$, exchangeable $\mathrm{NH}_{4}{ }^{+}$, available $\mathrm{NO}_{3}{ }^{-}$and exchangeable cations. The results were analysed using SAS and treatments means were compared using Duncan's New Multiple Range Test (DNMRT). Results: The use of humic molecules reduced $\mathrm{NH}_{3}$ loss and increased exchangeable $\mathrm{NH}_{4}{ }^{+}$. The high CEC of Humic Acids (HA) made the LHA treatment the best in reducing $\mathrm{N}$ loss after surface application. The presence of HA and Fulvic Acids (FA) increased $\mathrm{NH}_{4}{ }^{+}$recovery. Even though, the soil $\mathrm{pH}$ of all the treatments were high, significant reduction of $\mathrm{N}$ loss was observed for humic molecules treatments. Conclusion: The use of liquid organic $\mathrm{N}$ fertilizer has the ability to reduce $\mathrm{NH}_{3}$ volatilization in acid soil. The use of both humic and fulvic acids could be effective in promoting $\mathrm{NH}_{4}{ }^{+}$retention. Thus, it can be concluding that, humic substances, in general, have great ability in controlling $\mathrm{NH}_{3}$ loss and retaining $\mathrm{NH}_{4}{ }^{+}$in acid soils. It could be a cheapest, practical and easiest way to control $\mathrm{N}$ loss.
\end{abstract}

Key words: Ammonia volatilization, humic acids, fulvic acids, liquid N fertilizers, ammonium, nitrate

\section{INTRODUCTION}

Ammonia $\left(\mathrm{NH}_{3}\right)$ loss from volatilization processes reduces urea-N fertilizer use efficiency ${ }^{[1,2]}$. According to Raun and Johnson ${ }^{[3]}$, worldwide N Use Efficiency (NUE) was approximately 33\%. This low value suggests the environmental problems associated with the use of unbalanced $\mathrm{N}$ fertilizers. In considering the economic aspect, $67 \%$ loss was estimated to cost USD 15.9 billion. This huge amount of money does not include that needed in maintaining a clean environment with the existence of problems created due to unbalanced use of $\mathrm{N}$ fertilizers.
Under normal conditions, ammonium $\left(\mathrm{NH}_{4}{ }^{+}\right)$, hydroxyl $\left(\mathrm{OH}^{-}\right)$and carbonate $\left(\mathrm{CO}_{3}{ }^{2-}\right)$ ions are produced rapidly ( 1 or 2 days) after surface application of urea by urease ${ }^{[4]}$. This leads to the accumulation of $\mathrm{NH}_{4}{ }^{+}$, which simultaneously increases the soil $\mathrm{pH}$ surrounding the application area or near the urea granule ${ }^{[1]}$. The increase of $\mathrm{OH}^{-}, \mathrm{HCO}_{3}{ }^{-}$and $\mathrm{NH}_{4}{ }^{+}$ concentrations through this process plays a significant role in the rapid loss of $\mathrm{N}$. Rapid liberation of ammoniacal $\mathrm{N}$ makes it more fragile, which promotes soluble $\mathrm{N}$ (e.g., $\mathrm{NH}_{4}{ }^{+}$) to react with other components in the soil solution and releases $\mathrm{NH}_{3}$ gas to the atmosphere $^{[5]}$. Global estimation of $\mathrm{N}$ loss from urea

Corresponding Author: Osumanu Haruna Ahmed, Department of Crop Science, Faculty of Agriculture and Food Sciences, University Putra Malaysia Bintulu Campus, Sarawak, Malaysia Tel: +6086855406 Fax: +608685415 
alone has been estimated at $9 \mathrm{Tg} \mathrm{N}$ year ${ }^{-1[6]}$. While, overall losses from all possible sources reaches up to $54 \mathrm{Mt}$ (or $10^{-12} \mathrm{~g}$ ) $\mathrm{NH}_{3}-\mathrm{N}$ year ${ }^{-1[7]}$. It must be stressed that, huge losses of $\mathrm{N}$ could be one of the critical environmental issues that contribute to global warming.

There are many factors involved in $\mathrm{NH}_{3}$ volatilization, which can be grouped into soil (e.g., $\mathrm{pH}$, CEC), environment (e.g., temperature, humidity) and management (e.g., surface application, drilling). A number of studies with different approaches has reduced $\mathrm{NH}_{3}$ loss ${ }^{[1,2,8-11]}$. Acidic materials alone, organic and inorganic additives, mixture of acidic materials and additives could reduce $\mathrm{N}$ loss by $60,38.5$ and $49 \%$, respectively ${ }^{[1,2,9-11]}$. Generally, the main concerns for the above mixtures are that they create an acidic environment from acidic materials used and inhibit ureolytic microorganisms' activities which in effect slows down the release of $\mathrm{NH}_{4}{ }^{+}$into the soil and indirectly reduces $\mathrm{N}$ loss ${ }^{[12]}$.

In this regard, a new or better fertilizer formulation needs to be developed from organic based materials, which have the capability to retain $\mathrm{NH}_{4}{ }^{+}$(due to high CEC) as well as maintaining low soil $\mathrm{pH}$. Thus, the objectives of this laboratory study were to evaluate the effectiveness of liquid humic and fulvic acids, isolated from tropical peat soils, in reducing $\mathrm{N}$ loss from urea fertilizer as well as to investigate the ability of these acids to retain $\mathrm{NH}_{4}{ }^{+}$and $\mathrm{NO}_{3}{ }^{-}$.or reduce soil $\mathrm{pH}$.

\section{MATERIALS AND METHODS}

Mineral and peat soil samples were collected at 0$25 \mathrm{~cm}$ depth from minimal disturbed area of Universiti Putra Malaysia Bintulu Campus, Sarawak and Kuala Tatau, Sarawak, Malaysia respectively. The mineral soil was a sandy clay loam Typic Paleudults (Nyalau series) and the peat soil was Saprists (well decomposed humic matter). Both soils were air dried, ground and sieved to pass through $2 \mathrm{~mm}$ size.

The soil $\mathrm{pH}$ was analyzed using a glass electrode, organic carbon by combustion method ${ }^{[12]}$, CEC by leaching with ammonium acetate at $\mathrm{pH} 7$ before steam distillation $^{[13]}$ and exchangeable cations (K, Ca and $\mathrm{Mg}$ ) using Atomic Absorption Spectrophotometry (AAS). Prior to treatments preparation, humic acid (HA) was isolated according to the method of Susilawati et al. ${ }^{[14]}$. Extraction time of $4.5 \mathrm{~h}$ using a mechanical shaker at $188 \mathrm{rpm}$, acidification with $6 \mathrm{~N} \mathrm{HCl}$, fractionation under room temperature for $2 \mathrm{~h}$ and centrifugation time of 15 min were adopted for preparation of liquid humic acid (LHA) and Liquid Fulvic Acid (LFA). The mixture of LHA+LFA (acidified) and LHA+LFA (unacidified) were prepared by including or excluding the acidification step and without centrifugation. All treatments had a ratio of 4:50 [urea $(\mathrm{g})$ : Distilled water $(\mathrm{mL})]$. Treatments evaluated in this study were; T0-soil alone, T1-urea (liquid), T2-urea (solid), T3-LHA+Urea, T4-LFA+urea, T5-LHA+LFA (acidified)+urea, T6LHA+LFA (unacidified)+urea and (T7) ammonium sulphate (liquid).

Ammonia volatilization from the formulated fertilizers was evaluated in a laboratory incubation experiment. A closed dynamic air flow system with modification was used to measure the volatilized $\mathrm{NH}_{3}{ }^{[15]}$. The system consisted of: (1) Air pump with the flow rates ranging from 1-2 $\mathrm{L} \mathrm{min}^{-1}$ and (2) An exchange chamber (500 mL Erlenmeyer flask) and a trap (250 mL Erlenmeyer flask), both stoppered and fitted with an inlet/outlet. An inlet was connected to the chamber with air pump, whilst the outlet was connected to the trap containing boric acid using polyethylene tube. A $250 \mathrm{~g}$ of mineral soil was placed in the exchange chamber to a depth of $3 \mathrm{~cm}$. The soils were then moistened with liquid organic fertilizers (as treatments) or liquid urea and/or distilled water up to $75 \%$ field capacity. The moisture was maintained throughout the experiment by weighing the samples daily and distilled water was used to top up the difference.

Ammonia was collected in boric acid by air flow circulation, which passed through the exchange chamber into the trapping flask containing $100 \mathrm{~mL}$ boric acid with bromocresol green and methyl red indicator. It was then titrated with $0.01 \mathrm{M} \mathrm{HCl}$ to estimate the $\mathrm{NH}_{3}$ released. The data was collected every $24 \mathrm{~h}$ for 30 days. At the end of the experiment, the soil samples were removed and air dried. The soil samples were then analyzed for $\mathrm{pH}$ (water and $\mathrm{KCl}$ ), exchangeable $\mathrm{NH}_{4}{ }^{+}$and $\mathrm{NO}_{3}{ }^{-}$and cations (double acid method) ( $\mathrm{K}$, $\mathrm{Ca}$ and $\mathrm{Mg}$ ) using atomic absorption spectrometer (AAS-800). The experiment was conducted using a Completely Randomized Design (CRD), with three replications. Treatment effects were assessed using analysis of variance while treatment means were compared using Duncan's New Multiple Range Test (DNMRT). Statistical Analysis System (SAS) version 9.1 was used for the statistical analysis.

\section{RESULTS}

The mineral soil (Nyalau series) $\mathrm{pH}$ was acidic in water and $\mathrm{KCl}$ (Table 1). The soil contained $0.26 \% \mathrm{~N}$, $2.99 \%$ total organic carbon and $5.16 \%$ organic matter. Low exchangeable cations ( $\mathrm{K}, \mathrm{Ca}$ and $\mathrm{Mg}$ ) was recorded (Table 1). The CEC was $24.5 \mathrm{cmol} \mathrm{kg}^{-1}$. 
These information are consistent with those reported by Paramananthan ${ }^{[16]}$.

Table 1: Selected chemical properties of nyalau series

\begin{tabular}{|c|c|}
\hline Property & Values \\
\hline $\mathrm{pH}_{\mathrm{w}}$ & 4.040 \\
\hline $\mathrm{pH}_{\mathrm{KCl}}$ & 3.490 \\
\hline Exchangeable $\mathrm{K}^{+}\left(\mathrm{cmol} \mathrm{kg}^{-1}\right)$ & 0.113 \\
\hline Exchangeable $\mathrm{Ca}^{2+}\left(\mathrm{cmol} \mathrm{kg}^{-1}\right)$ & 1.002 \\
\hline Exchangeable $\mathrm{Mg}^{2+}\left(\mathrm{cmol} \mathrm{kg}^{-1}\right)$ & 1.001 \\
\hline $\mathrm{CEC}\left(\mathrm{cmol} \mathrm{kg}^{-1}\right)$ & 24.500 \\
\hline Total nitrogen (\%) & 0.260 \\
\hline Total organic carbon $(\%)$ & 2.990 \\
\hline Organic matter $(\%)$ & 5.160 \\
\hline $\mathrm{C} / \mathrm{N}$ ratio & 11.500 \\
\hline
\end{tabular}

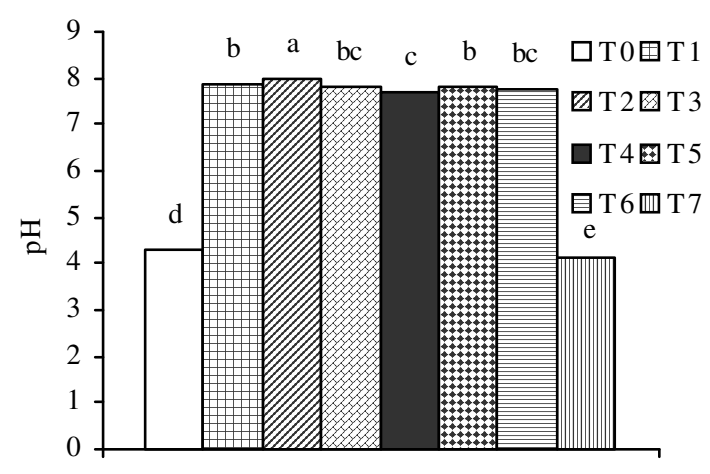

Fig. 1: Soil $\mathrm{pH}_{\mathrm{w}}$ after 30 days of incubation. (Different letter indicate significant difference between means using Duncan's New Multiple Range Test $($ DNMRT) at $\mathrm{p}=0.05)$

The $\mathrm{pH}$ (water and $\mathrm{KCl}$ ) recorded for treated soils were significantly different between treatments (Fig. 1 and 2). Soil treated with $\mathrm{T} 1$ or $\mathrm{T} 2$ gave higher $\mathrm{pH}_{\mathrm{w}}$ value as compared to other treatments; the highest was noted for T2. T5 was the third highest. Statistically it was not different from T1. As compared to T0 and T7, the $\mathrm{pH}_{\mathrm{w}}$ of the treated soil with urea (T1 and T2) and organically based liquid $\mathrm{N}$ fertilizers (T3 to $\mathrm{T} 6$ ) was significantly higher. Interestingly, T3 gave almost similar $\mathrm{pH}_{\mathrm{w}}$ values with $\mathrm{T} 6$; and these two treatments only showed their differences from $\mathrm{T} 2, \mathrm{~T} 0$ and $\mathrm{T} 7$. Even though T3 gave the highest $\mathrm{pH}$ value (9.04) during liquid organic fertilizer formulation (Table 2), its effect was temporary. After 30 days of incubation, the $\mathrm{pH}$ recorded for $\mathrm{T} 3$ was among the lowest, among organically based liquid $\mathrm{N}$ fertilizers treatments. The lowest $\mathrm{pH}_{\mathrm{w}}$ was recorded for $\mathrm{T} 7$ treatment followed by T0 and T4. In considering the effect of humic substances in reducing $\mathrm{pH}_{\mathrm{w}}$, treated with urea, LFA was better among liquid organic $\mathrm{N}$ fertilizer treatments.

In $\mathrm{KCl}$ solution, the treatments gave different results. The highest $\mathrm{pH}_{\mathrm{KCl}}$ was recorded for $\mathrm{T} 5$, followed by T1, T2 and T4 (Fig. 2). These four treatments were not significantly different. However, they were significantly different from $\mathrm{T} 6$ and $\mathrm{T} 3$. Table 2: Average $\mathrm{pH}$ values of formulated liquid fertilizers

\begin{tabular}{llll}
\hline & & \multicolumn{2}{c}{$\mathrm{pH}$} \\
Code & Treatment & Without urea & With urea \\
\hline F1 & Urea (liquid) & Nd & 8.14 \\
F2 & HA & 1.89 & 9.04 \\
F3 & FA & 1.02 & 1.64 \\
F4 & HA+FA (acidified) & 0.98 & 1.60 \\
F5 & HA+FA (unacidified) & 6.56 & 6.89 \\
\hline
\end{tabular}

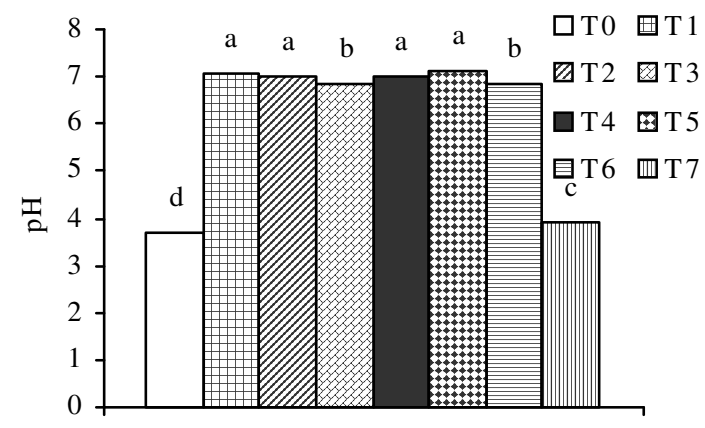

Fig. 2: Soil $\mathrm{pH}_{\mathrm{KCl}}$ after 30 days of incubation. (Different letter indicate significant difference between means using Duncan's New Multiple Range Test $(\mathrm{DNMRT})$ at $\mathrm{p}=0.05$ )

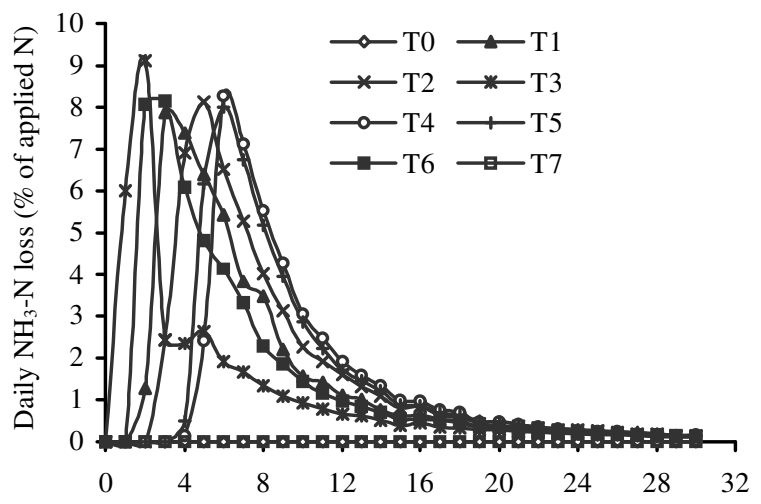

Fig. 3: Daily loss of ammonia for 30 days of incubation

As compared to $\mathrm{T} 0$ and $\mathrm{T} 7$, all the treatments with liquid organic based $\mathrm{N}$ fertilizers showed higher and significant results.

Daily $\mathrm{NH}_{3}$ loss from $\mathrm{T} 1$ and $\mathrm{T} 2$ was maximum at day $3(7.89 \%)$ and day $5(8.12 \%)$, respectively (Fig. 3). $\mathrm{T} 4$ and $\mathrm{T} 5$ recorded similar peaks of $\mathrm{NH}_{3}$ loss (6 days after treatments application). However, T6 and T3 showed a different trend.

$\mathrm{T} 4$ delayed $\mathrm{N}$ loss by 1-2 days as compared to $\mathrm{T} 2$ and T1, respectively. Similar result was noted for T5 treatment. T6 had no effect in delaying the $\mathrm{N}$ loss. In 
the case of T3 treatment, $\mathrm{N}$ loss occurred a day earlier compared to T2 and 2 days earlier compared to T1. Table 3: Cummulative $\mathrm{NH}_{3}$ loss for 30 days of incubation

\begin{tabular}{llll}
\hline Label & Treatment & $\begin{array}{l}\text { N loss } \\
(\%)\end{array}$ & $\begin{array}{l}\text { Reduction } \\
\text { obtained as } \\
\text { compared } \\
\text { to T2 (\%) }\end{array}$ \\
\hline T0 & Control & $0^{\mathrm{c}}$ & $\mathrm{nd}$ \\
T1 & Urea (liquid) & $48.74^{\mathrm{ab}}$ & 3.88 \\
T2 & Urea (solid) & $50.71^{\mathrm{a}}$ & $\mathrm{nd}$ \\
T3 & LHA plus urea & $35.90^{\mathrm{c}}$ & 29.21 \\
T4 & LFA plus urea & $44.91^{\mathrm{b}}$ & 11.44 \\
T5 & LHA+LFA (acidified)+urea & $46.60^{\mathrm{ab}}$ & 8.11 \\
T6 & LHA+LFA (unacidified)+urea & $48.65^{\mathrm{ab}}$ & 4.06 \\
T7 & Ammonium sulphate (liquid) & $0^{\mathrm{d}}$ & 100 \\
\hline
\end{tabular}

Different letter indicate significant difference between means using Duncan's New Multiple Range Test (DNMRT) at $\mathrm{p}=0.05 ; *$ nd $=$ Not Determine

Table 4: Soil exchangeable $\mathrm{NH}_{4}{ }^{+}$and available $\mathrm{NO}_{3}{ }^{-}$contents for 30 days of incubation

\begin{tabular}{llcl}
\hline Label & Treatment & $\begin{array}{l}\mathrm{NH}_{4}{ }^{+} \\
\left(\mathrm{mg} \mathrm{kg}^{-1}\right)\end{array}$ & $\begin{array}{l}\mathrm{NO}_{3}{ }^{-} \\
\left(\mathrm{mg} \mathrm{kg}^{-1}\right)\end{array}$ \\
\hline T0 & Control & $12.60^{\mathrm{d}}$ & $10.27^{\mathrm{c}}$ \\
T1 & Urea (liquid) & $170.80^{\mathrm{c}}$ & $12.13^{\mathrm{bc}}$ \\
T2 & Urea (solid) & $170.80^{\mathrm{c}}$ & $12.13^{\mathrm{bc}}$ \\
T3 & LHA plus urea & $179.67^{\mathrm{c}}$ & $11.20^{\mathrm{bc}}$ \\
T4 & LFA plus urea & $224.00^{\mathrm{b}}$ & $12.13^{\mathrm{bc}}$ \\
T5 & LHA+LFA (acidified)+urea & $217.00^{\mathrm{b}}$ & $18.67^{\mathrm{ab}}$ \\
T6 & LHA+LFA (unacidified)+urea & $172.20^{\mathrm{c}}$ & $12.13^{\mathrm{bc}}$ \\
T7 & Ammonium sulphate (liquid) & $774.20^{\mathrm{a}}$ & $21.00^{\mathrm{a}}$ \\
\hline
\end{tabular}

Different letter indicate significant difference between means using Duncan's New Multiple Range Test (DNMRT) at $\mathrm{p}=0.05$

The minimum period for maintaining significant $\mathrm{N}$ loss ( $1 \%$ from added $\mathrm{N}$, as urea) was different for all the treatments. Generally effects of organically based $\mathrm{N}$ fertilizers were different, vis a vis organic molecules type used in fertilizer formulation. In this study, presence of LHA (T3) required a minimum of 10 days to reach $1 \% \mathrm{~N}$ loss, whilst $\mathrm{T} 6$ required 12 days. Thirteen and 15 days were recorded for $\mathrm{T} 1$ and $\mathrm{T} 2$, respectively.

In general, the used of organic additives (e.g., LHA or LFA separately or their mixture) significantly reduced $\mathrm{N}$ loss (Table 3). Significant reduction of cumulative $\mathrm{N}$ loss, of $29.21 \%$ was recorded for $\mathrm{T} 3$ followed by $\mathrm{T} 4$ (Table 3). Other liquid organic $\mathrm{N}$ fertilizers treatments gave no significant effect as compared to $\mathrm{T} 1$.

Exchangeable $\mathrm{NH}_{4}{ }^{+}$and $\mathrm{NO}_{3}{ }^{-}$content in the soil were significantly different among treatments. The highest $\mathrm{NH}_{4}{ }^{+}$recovery was recorded for T7 treatment (Table 4). It was followed by $\mathrm{T} 4$ and T5. Lowest $\mathrm{NH}_{4}{ }^{+}$ recovery was recorded for $\mathrm{T} 1$ and $\mathrm{T} 2$ followed by $\mathrm{T} 3$. Other organic additives did not result in any significant difference as compared to $\mathrm{T} 1$ and $\mathrm{T} 2$. The effect of $\mathrm{T} 0$, T1, T2, T3, T4, T5 and $\mathrm{T} 6$ on soil available $\mathrm{NO}_{3}{ }^{-}$was not significantly different from $\mathrm{T} 7$ (Table 4). The $\mathrm{NO}_{3}$ was generally low in the soil after 30 days of incubation (Table 4).

Table 5: Soil exchangeable $\mathrm{K}, \mathrm{Ca}, \mathrm{Mg}$ and $\mathrm{Na}$ for 30 days of incubation

\begin{tabular}{lllll}
\hline & \multicolumn{3}{c}{ Exchangeable cations $\left(\mathrm{cmol} \mathrm{kg}^{-1}\right)$} \\
Label & $\mathrm{K}$ & $\mathrm{Ca}$ & $\mathrm{Mg}$ & $\mathrm{Na}$ \\
\hline T0 & $0.119^{\mathrm{c}}$ & $0.754^{\mathrm{a}}$ & $0.715^{\mathrm{a}}$ & $0.138^{\mathrm{b}}$ \\
T1 & $0.113^{\mathrm{c}}$ & $0.565^{\mathrm{b}}$ & $0.399^{\mathrm{cd}}$ & $0.120^{\mathrm{b}}$ \\
T2 & $0.117^{\mathrm{c}}$ & $0.592^{\mathrm{b}}$ & $0.376^{\mathrm{d}}$ & $0.121^{\mathrm{b}}$ \\
T3 & $0.127^{\mathrm{c}}$ & $0.588^{\mathrm{b}}$ & $0.412^{\text {bcd }}$ & $0.137^{\mathrm{b}}$ \\
T4 & $0.199^{\mathrm{b}}$ & $0.628^{\mathrm{b}}$ & $0.419^{\mathrm{bc}}$ & $0.126^{\mathrm{b}}$ \\
T5 & $0.221^{\mathrm{a}}$ & $0.633^{\mathrm{b}}$ & $0.445^{\mathrm{b}}$ & $0.130^{\mathrm{b}}$ \\
T6 & $0.215^{\mathrm{ab}}$ & $0.640^{\mathrm{b}}$ & $0.407^{\mathrm{bcd}}$ & $0.135^{\mathrm{b}}$ \\
T7 & $0.123^{\mathrm{c}}$ & $0.817^{\mathrm{a}}$ & $0.684^{\mathrm{a}}$ & $0.333^{\mathrm{a}}$ \\
\hline Different & &
\end{tabular}

Different letter indicate significant difference between means using Duncan's New Multiple Range Test (DNMRT) at $p=0.05$

Increase of exchangeable $\mathrm{K}$ was recorded for all of the liquid organic $\mathrm{N}$ fertilizers (Table 5). As compared to $\mathrm{T} 1, \mathrm{~T} 4, \mathrm{~T} 5$ and $\mathrm{T} 6$ gave a range of 76 to $95 \%$ increase in exchangeable $\mathrm{K}$. Other treatments [including $\left(\mathrm{NH}_{4}\right)_{2} \mathrm{SO}_{4}$ ] gave no significant results, as compared to $\mathrm{T} 0$ or $\mathrm{T} 1$ and $\mathrm{T} 2$. Exchangeable $\mathrm{Ca}$ and $\mathrm{Mg}$ from $\mathrm{T} 1, \mathrm{~T} 2, \mathrm{~T} 3, \mathrm{~T} 4, \mathrm{~T} 5$ and $\mathrm{T} 6$ treatments were lower compared to $\mathrm{T} 0$ and $\mathrm{T} 7$. They did not show any statistical difference among them. The highest content of exchangeable $\mathrm{Na}$ was noted for $\mathrm{T} 7$ treatment. It was significantly different from those of $\mathrm{T} 0$, urea (T1 and $\mathrm{T} 2$ ) and all organically based liquid $\mathrm{N}$ fertilizers (T3 to T6). The Na contents of the other treatments were only significantly different from that of $\mathrm{T} 0$.

\section{DISCUSSION}

As expected, solid form of urea resulted in higher $\mathrm{pH}_{\mathrm{w}}$ value compared to other treatments. This was probably due to hydrolysis processes that occurred just after application of urea fertilizer. Hydrogen released mainly by hydrolysis of Al, non-exchangeable hydroxyl $\mathrm{Al}$ and $\mathrm{Fe}$ and dissolution of organic matter, could be used during urea hydrolysis. This process generates $\mathrm{OH}^{-}$which accumulate not only at the microsite but completely in the soil ${ }^{[17]}$. This may have contributed to the increase of $\mathrm{pH}$. Even though some of the fertilizer mixtures [e.g; T5 (1.60), T4 (1.64)] (Table 2), used in this study were acidic, the $\mathrm{pH}$ increased sharply after 30 days of incubation. Higher quantity of $\mathrm{H}^{+}$(due to $\mathrm{HCl}$ during fractionation stage) in these mixtures could have facilitated urea hydrolysis and promoted the production of $\mathrm{OH}^{-}$.

Ammonium sulphate was the effective fertilizer in reducing the soil $\mathrm{pH}$ because $\mathrm{N}$ fertilizer, in the form of $\mathrm{NH}_{4}{ }^{+}$has the ability to react during nitrification in soils 
(equations 1 and 2) to produce acidic residues in the form of $\mathrm{H}^{+}, \mathrm{NO}_{3}{ }^{-}$and even $\mathrm{SO}_{4}{ }^{2-}$. According to Foth and Ellis ${ }^{[18]}$, almost $12 \mathrm{~kg}$ of $\mathrm{CaCO}_{3}$ will be needed in recovering the acidity by $\left(\mathrm{NH}_{4}\right)_{2} \mathrm{SO}_{4}$ in $1 \mathrm{~kg}$ soil:

$\left(\mathrm{NH}_{4}\right)_{2} \mathrm{SO}_{4}+4 \mathrm{O}_{2} \rightarrow 4 \mathrm{H}^{+}+2 \mathrm{NO}_{3}+\mathrm{SO}_{4}{ }^{-2}+2 \mathrm{H}_{2} \mathrm{O}$

$\left(\mathrm{NH}_{4}\right)_{2} \mathrm{SO}_{4}+4 \mathrm{O}_{2} \rightarrow 2 \mathrm{HNO}_{3}+\mathrm{H}_{2} \mathrm{SO}_{4}+2 \mathrm{H}_{2} \mathrm{O}$

The CEC provided by HA, which ranged between $417-583 \mathrm{cmol} \mathrm{kg}^{-1}$ (based on our previous study) may have contributed to ammonia loss reduction. The negative sites due to ionization of carboxylic $(\mathrm{COOH})$ and phenolic $(\mathrm{OH})$ might have improved $\mathrm{NH}_{4}{ }^{+}$retention hence reduction in $\mathrm{N}$ loss ${ }^{[19]}$. These negative charges could develop with the level of salt and $\mathrm{pH}$, that occurred in soil ${ }^{[20,21]}$. More salt will produce more negative charge in soil. A similar situation will occur at high $\mathrm{pH}$. Thus, the presence of $\mathrm{KOH}$ (residues by extraction procedure), as a source of salt, could enhance $\mathrm{HA}$ charges and indirectly reducing the $\mathrm{N}$ loss.

The high $\mathrm{pH}$ recorded for water and $\mathrm{KCl}$ could be another factor for the efficient use of humic molecules in controlling $\mathrm{N}$ loss, due to high $\mathrm{pH}$ recorded and could increase the $\mathrm{CEC}^{[21,22]}$. Humic molecules have the ability to retain cations at their surfaces. The retention of $\mathrm{NH}_{4}{ }^{+}$might be a factor for the low available $\mathrm{NO}_{3}{ }^{-}$in soil. Reduction conversion of $\mathrm{NH}_{4}{ }^{+}$to $\mathrm{NO}_{3}{ }^{-}$would then occur due to lack of $\mathrm{NH}_{4}{ }^{+}$in soil solution. A similar observation has been reported by Ahmed et al. ${ }^{[23]}$.

The information on exchangeable $\mathrm{Ca}$ and $\mathrm{Mg}$ supports $\mathrm{NH}_{3}$ loss reduction. The increase in these two cations suggests that there was some replacement and retention of $\mathrm{NH}_{4}{ }^{+}$in the soil treated with liquid organic fertilizers ${ }^{[23]}$. Even though, no statistical difference was observed, the trend of $\mathrm{NH}_{3}$ loss provides early information on the relationship between $\mathrm{NH}_{4}{ }^{+}$retention, reduction of $\mathrm{N}$ loss and exchangeable cations.

T7 caused the highest exchangeable $\mathrm{Ca}, \mathrm{Mg}$ and $\mathrm{Na}$ in this study. This was expected for $\mathrm{NH}_{4}{ }^{+}-\mathrm{N}$ fertilized soils. Since the exchange sites of soils saturated with cations such as $\mathrm{Ca}, \mathrm{Mg}, \mathrm{Na}$ and $\mathrm{K}$ in the order of $\mathrm{Ca}>\mathrm{Mg}>\mathrm{K}>\mathrm{Na}$, more $\mathrm{NH}_{4}{ }^{+}$in particular is expected to be in soil solution for $\mathrm{T}^{[18]}$.

Higher exchangeable $\mathrm{K}$ recorded in some of the treatments was probably due to higher content of $\mathrm{K}$ associated with them. Based on our analysis, the content of $\mathrm{K}$ in fulvic acid solution was high, almost $2000 \mathrm{ppm}$ in $50 \mathrm{~mL}$. This value was 20 times higher as compared to LHA [previous paper, almost $100 \mathrm{ppm}$ in $50 \mathrm{~mL}$ (after 1st washing)]. In the case of T4, splitting LHA and LFA reduced the K content in LFA solution and this could be the reason why LFA gave lower exchangeable $\mathrm{K}$ as compared to T5 and T6 treatments.

\section{CONCLUSION}

Liquid organic $\mathrm{N}$ fertilizer has the ability to reduce $\mathrm{NH}_{3}$ volatilization in an acid soil. Even though, the amount used was small as compared to the quantity of soil used, the effect on $\mathrm{NH}_{3}$ loss cannot be ignored. HA was the most effective material that effectively controlled $\mathrm{NH}_{3}$ loss. The use of both humic and fulvic acids is effective in promoting $\mathrm{NH}_{4}{ }^{+}$retention. Thus, it can be concluded that, humic substances, in general, have a great ability in controlling $\mathrm{NH}_{3}$ loss and retaining $\mathrm{NH}_{4}{ }^{+}$in an acid soil. It could be one of the cheapest, easiest and practical ways in controlling $\mathrm{N}$ loss. However, the rate or amount that is most effective together with its possibility to be used as foliar fertilizer needs to be investigated in detail in future research.

\section{ACKNOWLEDGEMENT}

The researchers acknowledge the financial support of this research by the Ministry of Higher Education Malaysia.

\section{REFERENCES}

1. Fan, M.X. and A.F. MacKenzie, 1993. Urea and phosphate interactions in fertilizer microsites: ammonia volatilization and $\mathrm{pH}$ changes. Soil Sci. Soc. Am. J. 57: 839-845. http://soil.scijournals.org/cgi/reprint/57/3/839

2. Al-Kanani, T., A.F. MacKenzie and H. Blenkhorn, 1990. Volatilization of ammonia from ureaammonium nitrate solutions as influenced by organic and inorganic additives. Fertil. Res., 23: 113-119. DOI: $10.1007 / \mathrm{BF} 01063338$

3. Raun, W.R. and G.V. Johnson, 1999. Improving nitrogen use efficiency for cereal production. Agron. J., 91: 357-363. http://agron.scijournals.org/cgi/reprint/91/3/357

4. Zhengping, W., O. Van Cleemput, L. Liantie and L. Baert, 1991. Effect of urease inhibitors on urea hydrolysis and ammonia volatilization. Biol. Fertil. Soils, 11: 43-47. DOI: 10.1007/BF00335833

5. Hayashi, K., S. Nishimura and K. Yagi, 2008. Ammonia volatilization from a paddy field following applications of urea: Rice plants are both an absorber and an emitter for atmospheric ammonia. Sci. Total Environ., 390: 485-494. DOI: 10.1016/j.scitotenv.2007.10.037 
6. Oliver, J.G., A.F. Bouwman, K.W. Van der Hoek and J.J.M. berdowski, 1998. Global air emission inventories for anthropogenic sources of $\mathrm{NO}_{\mathrm{x}}, \mathrm{NH}_{3}$ and $\mathrm{N}_{2} \mathrm{O}$ in 1990. Environ. Pollut., 102: 135-148. DOI: 10.1016/S0269-7491(98)80026-2

7. Van Cleemput, O. and P. Boeckx, 2006. Nitrogen and its Transformations. In: Encyclopedia of Soil Science. Vol. 2, Lal, R. (Ed.). Taylor and Francis, New York, ISBN: 082470634X, pp: 1125.

8. Purakayastha, T.J. and J.C. Katyal, 1998. Evaluation of compacted urea fertilizers prepared with acid and non-acid producing chemical additives in three soils varying in $\mathrm{pH}$ and cation exchange capacity. Nutr. Cycl. Agroecosyst., 51: 117-121.

http://www.springerlink.com/content/xqqhr91766k 66045/fulltext.pdf

9. Lethbridge, G. and R.G. Burns, 1976. Inhibition of soil urease by organophosphorus insecticides. Soil Biol. Biochem., 8: 99-102. DOI: 10.1016/00380717(76)90072-9

10. Watson, C.J., H. Miller, P. Poland, D.J. Kilpatrick, M.D.B. Allen, M.K. Garrett and C.B. Christianson, 1994. Soil properties and the ability of urease inhibitors $\mathrm{N}$-(n-Butyl) thiophosphoric triamide (nBTPT) to reduce ammonia volatilization from surfaceapplied urea. Soil Biol. Biochem., 26: 1165-1171. DOI: 10.1016/0038-0717(94)90139-2

11. Zaman, M., M.L. Nguyen, J.D. Blennerhassett and B.F. Quin, 2007. Reducing $\mathrm{NH}_{3}, \mathrm{~N}_{2} \mathrm{O}$ and $\mathrm{NO}_{3}{ }^{-} \mathrm{N}$ losses from a pasture soil with urease or nitrification inhibitors and elemental S-amended nitrogenous fertilizers. Biol. Fertil. Soils. DOI: 10.1007/s00374-007-0252-4

12. Cheftetz, B., P.H. Hatcher, Y. Hadar and Y. Chen, 1996. Chemical and biological characterization of organic matter during composting of municipal solid waste. J. Environ. Qual., 25: 776-785. http://jeq.scijournals.org/cgi/reprint/25/4/776

13. Keeney, D.R. and D.W. Nelson, 1982. NitrogenInorganic Forms. In: Methods of Soil Analysis, Part 2, Page, A.L., D.R. Keeney, D.E. Baker, R.H. Miller, R. Ellis and J.D. Rhoades (Eds.). 2nd Edn., Agron. Monogr. 9. ASA and SSSA, Madison, WI., ISBN: 0891180729 (pt. 2).

14. Susilawati, K., O.H. Ahmed, A.B. Nik Muhamad and M.Y. Khanif, 2007. Effects of extraction and fractionation period on the yield of a tropical peat soil (Hemists) humic acids. Am. J. Agric. Biol. Sci., 2: 202-205.
15. Siva, K.B., H. Aminuddin, M.H.A. Husni and A.R. Manas, 1999. Ammonia volatilization from urea as affected by tropical-based palm oil mill effluent (pome) and peat. Commun. Soil Sci. Plant Anal., 30: 785-804.

DOI: $10.1080 / 00103629909370246$

16. Paramananthan, S., 2000. Soils of Malaysia: Their Characteristics and Identification. Vol. 1. Academy of Sciences Malaysia, Kuala Lumpur, ISBN: 9839445065.

17. Thomas, G.W. and W.L. Hargrove, 1984. The Chemistry of Soil Acidity. In: Soil Acidity and Liming, Fred Adams (Ed.). 2nd Edn., Agron. Monogr. 12. ASA, Madison, WI., ISBN: 0-89118080-X, pp: 3-55.

18. Foth, H.D. and B.G. Ellis, 1988. Soil and Fertilizer Nitrogen. In: Soil Fertility. John Wiley and Sons, Inc., United States of America, ISBN: 9780471825074.

19. Stevenson, F.H., 1994. Humus chemistry: Genesis, Composition, Reactions. 2nd Edn., Wiley, New York, ISBN: 978-0-471-59474-1, pp: 378-486.

20. Campitelli, P.A., M.I. Velasco and S.B. Ceppi, 2003. Charge development and acid-base characteristics of soil and compost humic acids. J. Chil. Chem. Soc., 48: 91-96.

21. Tan, K.H., 2003. Electrochemical Properties of Humic Matter. In: Humic Matter in Soil and the Environment: Principles and Controversies, Marcel Dekker, (Ed.). Inc., New York, ISBN: 0-82474272-9, pp: 386.

22. Bache, B.W., 2006. Ion Exchange. In: Encyclopedia of Soil Science, Vol. 1, Lal, R. (Ed.). Taylor and Francis, New York, ISBN: 082470634X, pp: 916-919.

23. Ahmed, O.H., H. Aminuddin, M.H.A. Husni, A.R. Anuar and A.M. Nik Muhamad, 2008. Enhancing the urea-N use efficiency in Maize (Zea mays) cultivation on acid soils amended with zeolite and TSP. Sci. World J., 8: 394-399. DOI: 10.1100/tsw.2008.68 